\section{Australian Journal of \\ Crop Science}

\title{
Synchronizing coffee blossoming and fruit ripening in irrigated crops of the Brazilian Cerrado Mineiro Region
}

\author{
Felipe Rodrigues Miranda ${ }^{1}$, Luis Cesar Dias Drumond ${ }^{2}$, Cláudio Pagotto Ronchi ${ }^{1}$ \\ ${ }^{1}$ Agrarian Science Institute, Federal University of Viçosa, Campus Florestal, Florestal, MG, 35690-000, Brazil \\ ${ }^{2}$ Agrarian Science Institute, Federal University of Viçosa, Campus Rio Paranaíba, Rio Paranaíba, MG, 38800-000, \\ Brazil
}

\section{*Corresponding author: claudiopagotto@ufv.br}

\section{Abstract}

\begin{abstract}
Non-uniform blossoming due to uninterrupted irrigation is common in perennial crops such as coffee. It usually leads to uneven ripening of fruits and impairs harvesting efficiency and quality of coffee. The effect of different water deficit periods was evaluated, associating them with the deficit level and development stage of the flower bud, on blossoming concentration in irrigated coffee plantations. We also evaluated the effect of water deficit on growth, productivity, maturation, and physical quality of the bean. Two identical trials were performed on 19-month-old Coffea arabica cultivars ('Catuaí Vermelho IAC 144' and 'Bourbon Amarelo $\mathrm{J}^{\prime}$ ), from June 2008 to July 2009. Irrigation was suspended and resumed at different times (seven treatments) at the pre-flowering stage using a randomized block design with four replicates. The cultivars reached different levels of deficit for the same period of suspended irrigation. In 'Catuai', 60\% of the flower buds opened after the coffee plants were exposed to water deficit from early or late June to early September. In 'Bourbon', even the longer water deficit period (06/09 to 09/07) did not induce blossoming greater than $20 \%$. Growth was slightly affected during the water withholding period, but not in the subsequent evaluations in October or January. In both cultivars, drought promoted a higher percentage of ripe cherries at harvest than continuous irrigation, regardless of treatment. In conclusion, although blossoming was not a single concentrated event, especially in 'Bourbon', withholding irrigation in the pre-flowering stage contributed to uniform fruit ripening in both Arabica coffee cultivars.
\end{abstract}

Keywords: Bean quality; Coffea arabica; flowering; fruit maturation; gas exchange; irrigation; reproductive growth; water stress. Abbreviations: $\Psi_{\mathbf{W}_{\mathrm{pd}}}$ Pre-dawn leaf water potential; Fig._Figure;T1_Treatment One (irrigated continuously); T2_Treatment Two: withholding irrigation from 06/09 to 09/07; T3_Treatment Three: withholding irrigation from 06/23 to 08/25; T4_Treatment Four: withholding irrigation from $06 / 23$ to 09/07; T5_Treatment Five: withholding irrigation from 07/07 to 08/25; T6_Treatment Six: withholding irrigation from 07/07 to 09/07; T7_Treatment Seven: withholding irrigation from 07/21 to 09/07; E3_flower bud development stage representing physiologically immature flower bud; E4_flower bud development stage representing physiologically mature flower bud, ripe-to-flower stage; E5_flower bud development stage after dormancy break, just before anthesis, when the buds appear completely white; E6_anthesis (opened flowers).

\section{Introduction}

Brazil is the main coffee producer and exporter in the world. In 2018, it is estimated that the Brazilian crop produced 59.9 million bags, which is the largest in the history of the country. The state of Minas Gerais leads the national ranking in terms of production with approximately 31.5 million bags of arabica coffee produced per year, of which 6.97 million bags were produced in the region of the Cerrado of Minas Gerais (Conab, 2018). The coffee production in this region is intensive (Fernandes et al., 2012; Matiello et al., 2016), leading to yields above the national average, which is currently 32.17 bags/ha (Conab, 2018). The high productivity is attributed to a combination of factors, such as mechanization, a favorable climate, and irrigation (Fernandes et al., 2012). The irrigation itself directly influences coffee production as it prevents water deficits, which could limit production under normal conditions, ensuring a higher productivity and better economic performance (Fernandes et al., 2016).

In the Cerrado, many coffee crops are irrigated throughout the year owing to low or heterogeneous rainfall, and because of the dry winter season (approximately 3-4 months) (Fernandes et al., 2016; Ronchi et al., 2015). However, this practice, along with sporadic spring rains, may result in non-uniform blossoming and subsequent unsynchronized fruit maturation (DaMatta et al., 2007). Irregular maturation, generally characterized by a lower ratio of cherry/green fruits, impairs mechanization, which is a technique that streamlines the process of harvesting, and also results in a high content of green and/or black beans at harvest, which reduces the quality of the coffee (Mesquita et al., 2016).

Past studies, such as those by Alvim (1960), Rees (1964), 
and Crisosto et al. (1992), and more recent studies, such as those by Guerra et al. (2005), Silva et al. (2009), and Ronchi et al. (2015), demonstrated the importance of dry periods during pre-flowering to disrupt the dormancy of the flower buds, preparing them to respond to stimuli for anthesis. In addition, Silva et al. (2009) showed that continuous irrigation during this period delayed and deregulated bud development. Therefore, by controlling the dry season, the dormancy period of the flower buds is also controlled. In theory, it is possible to synchronize or concentrate the flowering through adequate irrigation management (Ronchi et al., 2015).

During the flower initiation process, the buds-of-the-series receive inductive stimuli at different times, which results in different maturation stages. Thus, application of a water deficit for a certain period causes a delay in the further development of buds that are in more advanced physiological stages. If this delay is sufficient, the nonadvanced buds can complete the necessary physiological and morphological processes to be synchronized with the advanced ones. Therefore, a larger number of flower buds become simultaneously sensitive to the ecological factor for flower opening (DaMatta et al., 2007). The coffee tree has a seasonal growth pattern with reduced rates during the winter (the dry and cold season) (Amaral et al., 2006), particularly in several areas of the Cerrado of Minas Gerais (Fernandes et al., 2016), resulting in low evapotranspiration rates. Thus, adequate water deficit levels (Ronchi et al., 2015) can induce uniform flowering and fruit ripening, without significant detrimental effects to the crop, as previously verified in adverse situations (Guerra et al., 2005). Several studies (Schuch et al., 1992; Bomfim Neto, 2007; Ronchi et al., 2015; Silva et al., 2009; Miranda, 2020; Silva et al., 2009) have sought to find the adequate deficit level to induce uniform coffee flowering, without a significant effect on other physiological functions of the plants, such as photosynthesis, cell expansion, and leaf growth (Taiz et al., 2017). Once affected, this could lead to lower yields in future crops. However, the pre-dawn leaf water potential $\left(\Psi_{\mathrm{w}_{\mathrm{pd}}}\right)$ values in those studies were heterogeneous, with values of $-1.2 \mathrm{MPa}$ (Bomfim Neto, 2007), -1.1 to $-1.6 \mathrm{MPa}$ (Silva et al., 2009), and -2.65 MPa (Schuch et al., 1992). Under these circumstances, further studies are required to better define, for different field situations, the periods of suspension and resumption of irrigation that lead to the minimum water potentials that are required to disrupt dormancy (Ronchi and Miranda, 2020).

This study tested different periods of suspension and resumption of irrigation, associating them with the water deficit level and with the developmental stage of the flower bud, aiming at synchronizing the flowering in irrigated coffee crops of the Cerrado of Minas Gerais, Brazil. The effect of water deficit on the growth, productivity, maturation, and physical quality of the beans was also evaluated.

\section{Results and Discussion}

\section{Water deficit progress among coffee cultivars}

For both cultivars, the $\Psi_{\mathrm{w}_{\mathrm{pd}}}$ slowly decreased $(-0.09$ $\mathrm{MPa}$ /week) in the months of June and July, until mid-August. However, in the last week of August and the first week of September, there was a marked decrease in water potential, with an overall mean of-0.21 MPa/week (Fig. 1). The temperature variations explained this decrease: the mean and maximum temperatures were 19.7 and 25.5, 18.1 and 25.6, 21.2 and 30.1 , and 23.1 and $31.8^{\circ} \mathrm{C}$ in June, July, August, and September, respectively (Fig. 2). In addition, the mean maximum temperature in August was $29.6^{\circ} \mathrm{C}$ and it increased to $32.0^{\circ} \mathrm{C}$ in the last two weeks of the deficit, which probably led to high evapotranspiration rates (Ronchi et al., 2015) associated with low relative air humidity in a very short time, dehydrating the coffee tree (Taiz et al., 2017).

A lower decrease in $\Psi_{\mathrm{w}_{\mathrm{pd}}}(-0.038 \mathrm{MPa} /$ week) in 'Bourbon' than that in 'Catuai' (-0.057 MPa/week) was observed for the T2 data from $06 / 09$ to $08 / 25$ (Fig. 1). Therefore, the arabica coffee cultivars (planted side by side) showed different responses to irrigation suspension owing to their morphophysiological differences since the management and the edaphoclimatic conditions were the same in both crops. It should be noted that the leaf water status was the same among cultivars at the beginning of the experiment (Fig. 1). Therefore, 'Bourbon', compared to 'Catuaí', delayed tissue dehydration, presumably because of the thicker cuticle, which reduced transpiration, and the thicker palisade parenchyma, which allowed a greater $\mathrm{CO}_{2}$ fixation associated with the aperture of stomata in a shorter period of time (owing to a higher stomatal density), increasing water use efficiency (Batista et al., 2010). Nevertheless, it seems that the differences in dehydration rates among cultivars varied greatly from one year to the next, as confirmed by studies on these crops in subsequent years (Ronchi et al., 2015). The extent of defoliation after harvesting can probably explain such variation since transpiration is a phenomenon that depends on the leaf surface area (Taiz et al., 2017).

Considering the water status differences presented, 'Catuai' showed a $\Psi_{W_{p d}}$ of $-0.04,-1.42,-0.28,-1.15,-0.41,-1.23$, and $-1.15 \mathrm{MPa}$ in the measurements performed just before the resumption of irrigation for the treatments $\mathrm{T} 1$ to $\mathrm{T} 7$, respectively, whereas 'Bourbon' showed values of -0.05 , $0.91,-0.21,-0.71,-0.17,-0.83$, and $-0.57 \mathrm{Mpa}$ for T1 to T7, respectively. It should be noted that irrigation was resumed on $08 / 25$ for the T3 and T5 treatments and on 09/07 for the other treatments. Given the high transpiration rate in the last week of August and the first week of September, owing to the substantial increase in temperature (Fig. 2), more negative water potentials were observed in the treatments with a deficit period until 09/07 compared to treatments with irrigation resumption on $08 / 25$, in both cultivars (Fig. 1).

\section{Blossoming events according to the treatments}

During the entire water deficit period, between 06/09 and $09 / 07$, there was only one precipitation event that occurred on $08 / 05$ ( $8 \mathrm{~mm}-$ Fig. 2 ), and this triggered the opening of a few flowers on $08 / 17$, less than $8 \%$ in 'Catuaí' and less than $16 \%$ in 'Bourbon', regardless of the treatment (Figs. $3 \mathrm{~A}$ and $B)$. This rainfall $(8 \mathrm{~mm})$ is considered sufficient (perhaps the minimum required) for the resumption of bud growth and flower opening, and the rain and a cold front can provide the necessary meteorological conditions for flower opening, 
even in plants maintained under continuous irrigation (Ronchi et al., 2015; Soares et al., 2005). Sporadic and lowintensity rains (as the one in early August) are common in the Brazilian Cerrado regions where the dry season does not always fully occur every year, and these rains often limit the use of the water deficit as a strategy to synchronize flowering in many coffee production regions.

Two factors contributed to the low percentage of open flowers in early August. The first was the high leaf water potential in the flower buds (discussed in the earlier section), which implies that it had not yet reached sufficiently negative levels to disrupt the dormancy of the flower buds (Bomfim Neto, 2007; Silva et al., 2009). The second was related to most of the flower buds (approximately 90\%, Figs. 3A and B) not yet having enough physiological maturity to respond to the opening stimulus (Soares et al., 2005; DaMatta et al., 2007). In a study carried out in subsequent years in the same area and crop, Ronchi et al. (2015) found that $78 \%$ of the flower buds were in the immature (E3) or at most in the ripe-to-flower (E4) stages in early August.

After 90 (T2) or 76 (T4) days of water deficit in 'Catuai', which led to a $\Psi_{\mathrm{w}_{\mathrm{pd}}}$ of -1.42 and $-1.15 \mathrm{MPa}$, respectively, $60 \%$ of the flower buds opened in response to irrigation resumption (Fig. 3C). The flower opening of other deficit treatments did not differ from that of $\mathrm{T} 2$ (Fig. $3 \mathrm{C}$ ). Thus, this blossoming event in non-irrigated plants resulted in a higher percentage of pinheads compared to that in $\mathrm{T} 1$ in the following flowering on 09/28 (Fig. 3E), with few changes in the last flowering on 10/09, when deficit treatments (T2, T4, and T7) showed a higher pinhead percentage (Fig. 3G) owing to the cumulative effect of the previous flowering. These results, especially those of the higher water deficit treatments, suggest that the water deficit did not promote the concentration of the flowering into only a single event, but rather into several events within a shorter period of time. This supports the results reported by Soares (2005) that water stress, applied in the pre-flowering stage, accelerates the development of the flower bud.

Even after 90 days of water deficit in 'Bourbon', the $\Psi_{\mathrm{w}_{\mathrm{pd}}}$ was $-0.91 \mathrm{MPa}$, and this did not induce synchronized flowering after resumption of irrigation (Fig. 3D). In the measurements recorded on 09/28 (Fig. 3F) and 10/09 (Fig. $3)$, the treatments did not show significant differences ( $p>0.05$ ) for each stage analyzed. Even on 10/09 (Fig. 3H), a large proportion (approximately $42 \%$ ) of the flower buds were yet to open. This suggests that gregarious flower opening events were occurring gradually, as flower buds matured physiologically. In particular, the T5 treatment, which represented the water deficit pattern adopted at the farm, was ineffective in synchronizing flowering in either cultivar (Figs. 3C and D), since most buds did not open with this treatment when the irrigation was resumed.

Considering the maximum water potential value to disrupt dormancy is $-0.80 \mathrm{MPa}$ (Crisosto et al., 1992), the flower buds did not open in the treatments with the highest water deficit probably because the percentage of physiologically mature flower buds was as yet too low even in early September (Figs. $3 C$ and D), as discussed above. The importance of the physiological stage of the buds, so that they can receive stimuli for flower opening, has already been discussed in other studies such as Bomfim Neto (2007) and Ronchi et al. (2015). Thus, using either fixed dates (as proposed by Guerra et al., 2005) or measurements of the leaf water potential alone as a criteria might not induce synchronized flowering since these factors, in addition to others (such as temperature, relative humidity, genotype, and fruiting load), act synergistically to induce flowering (DaMatta et al., 2007).

\section{Coffee plant growth}

The evaluation of the growth changes of the coffee tree immediately after the end of the irrigation suspension period (thus on 09/14) in all treatments (Fig. 4) showed that only $T 2$, compared to $T 1$, significantly reduced the number of nodes in the plagiotropic branch in 'Catuaí' (Fig. 4A; from 1.375 to 0.875 nodes/branch), but it did not affect the length (Fig. 4C), leaf area accumulation (Fig. 4E), or the height of the plants (Fig. 4G). In 'Bourbon', all these growth variables were affected to some degree by the water deficit treatments ( $T 2$ to $T 7$ ), in comparison to $T 1$, even though variations were observed among treatments (Figs. 4B, D, F, and $H$ ). In general, the effect on growth was discrete, even in 'Bourbon', since the coffee tree naturally exhibits a low growth rate from June to August owing to the reduced minimum temperatures (Amaral et al., 2006; DaMatta et al., 2007) (Fig. 2).

However, no significant differences in crop growth were observed between treatments when growth measurements were taken on 10/26 (transition from the pinhead stage to rapid swelling) and 01/17 (beginning of endosperm filling stage)(Fig. 4). Presumably, a compensatory growth (DaMatta et al., 2007) occurred in the water deficit treatments since the deficit was not severe (Fig. 1) and the decrease in growth, in practical terms, was not very expressive. Growth is a physiological activity that is most sensitive to water deficit, since it depends on the turgor pressure of the cell which exerts pressure on the cell wall; thus, expanding the cell (Taiz et al., 2017). When the deficit reaches more severe levels (which did not occur in this study) and the plant is subjected to higher temperatures, there are other consequences that may compromise the crop, such as photosynthetic limitations, oxidative stresses, and cavitation (DaMatta et al., 2007), which possibly explains, not only the growth loss, but also the significant productivity losses observed by Guerra et al. (2005). For the Brazilian Cerrado region, where the present study was conducted, in the $2008 / 2009$ harvest, the coffee tree growth was not strongly affected by a relatively long deficit period (or irrigation suspension) owing to the low evapotranspiration, and it is thus possible to implement the method in a planned manner.

\section{Coffee fruit maturation}

For both cultivars, the percentage of unripe cherries (green fruit) at harvest time was significantly higher in T1 (continuous irrigation of the coffee tree during the winter), reaching means of $25 \%$ in 'Catuaí' and $43 \%$ in 'Bourbon'. This resulted in a low percentage of cherries; that is, $48 \%$ and $40 \%$ in 'Catuaí' and 'Bourbon', respectively (Fig. 5). However, the mean percentage of cherries was significantly higher in the deficit treatments ( $T 2$ to $\mathrm{T} 7$ ) compared to the treatment with continuous irrigation (T1), with values as high as $76 \%$ for the T4 in 'Catuaí' and 73\% for the T2 in 'Bourbon' (Fig. 5). 


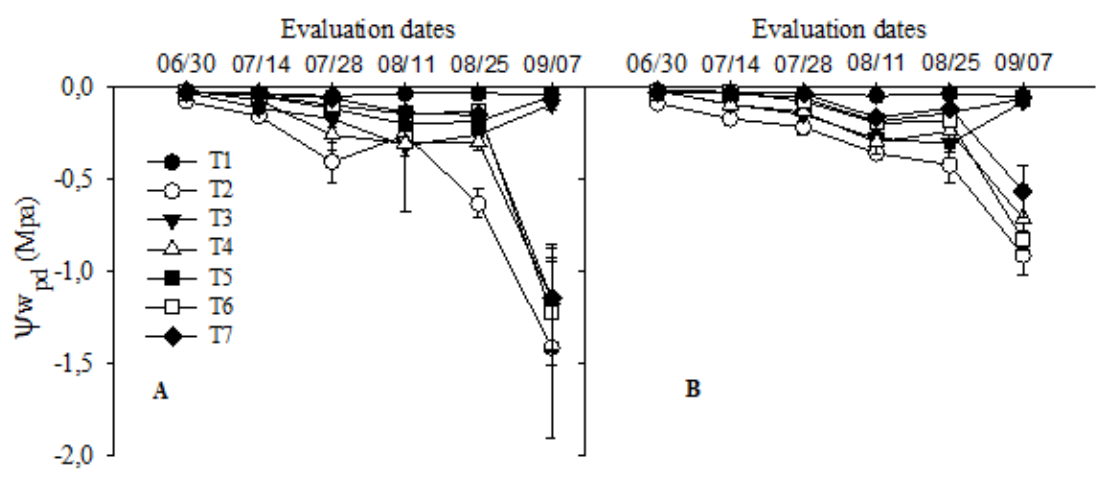

Fig 1. Pre-dawn leaf water potential $\left(\Psi_{\mathrm{W}_{\mathrm{pd}}}\right)$ evaluated biweekly in two arabica coffee cultivars, 'Catuaí Vermelho' (A) and 'Bourbon Amarelo'(B), for the following treatments applied at the crop pre-flowering stage: T1: irrigated continuously; T2: 06/09 to 09/07 (irrigation withholding period); T3: 06/23 to 08/25; T4: 06/23 to 09/07; T5: 07/07 to 08/25; T6: 07/07 to 09/07; T7: 07/21 to 09/07. Treatments were ended with the resumption of irrigation on 08/25 or 09/07. Each point in the graph represents the mean \pm standard error of the mean $(n=4)$.

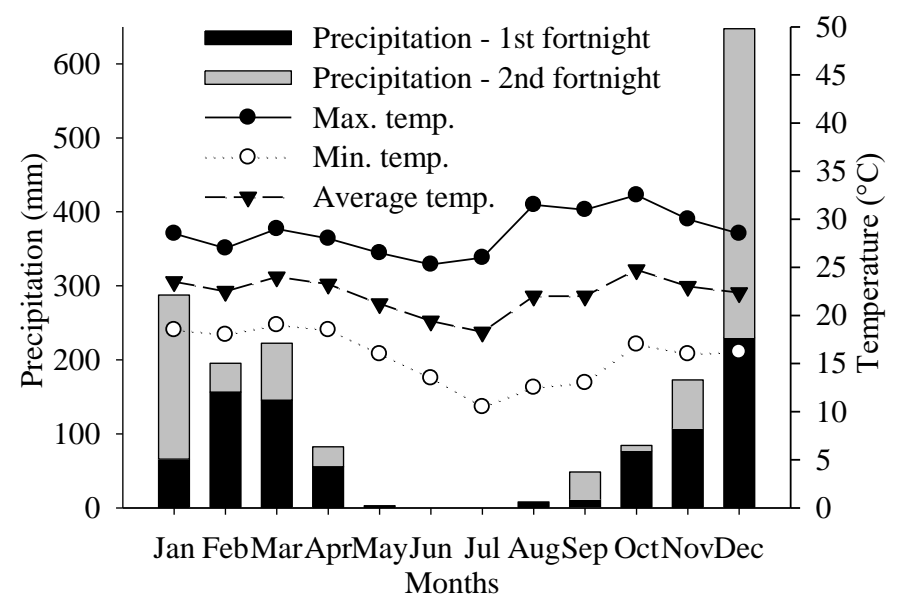

Fig 2. Monthly mean precipitation in each fortnight and maximum, mean, and minimum monthly temperature in 2008 . The first rains at the end of the winter period occurred on 08/08 (8 mm), 09/15-16 (16 mm), and 09/20-21 (23 mm).

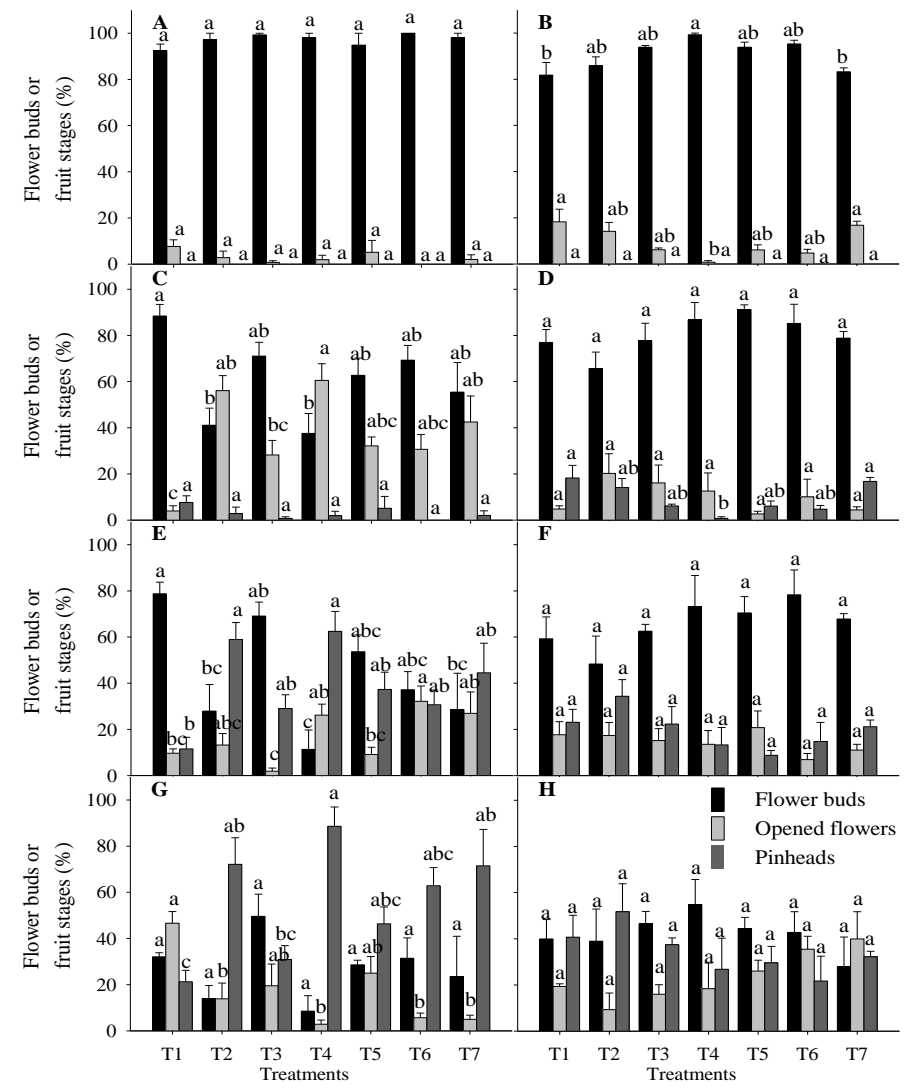

Fig 3. Percentage of flower buds, opened flowers, and fruits at the pinhead stage in cultivars 'Catuaí Vermelho IAC 144' (left) and 'Bourbon Amarelo J9' (right) on 08/17 $(A$ and $B), 09 / 14$ ( $C$ and $D), 09 / 28(E$ and $F)$ and 10/09 (G and H). For each stage, bars associated with the same letter indicate no significant differences between treatments, as indicated by the Tukey's test set at $5 \%$ probability. See Figure 1 for a description of the treatments. 


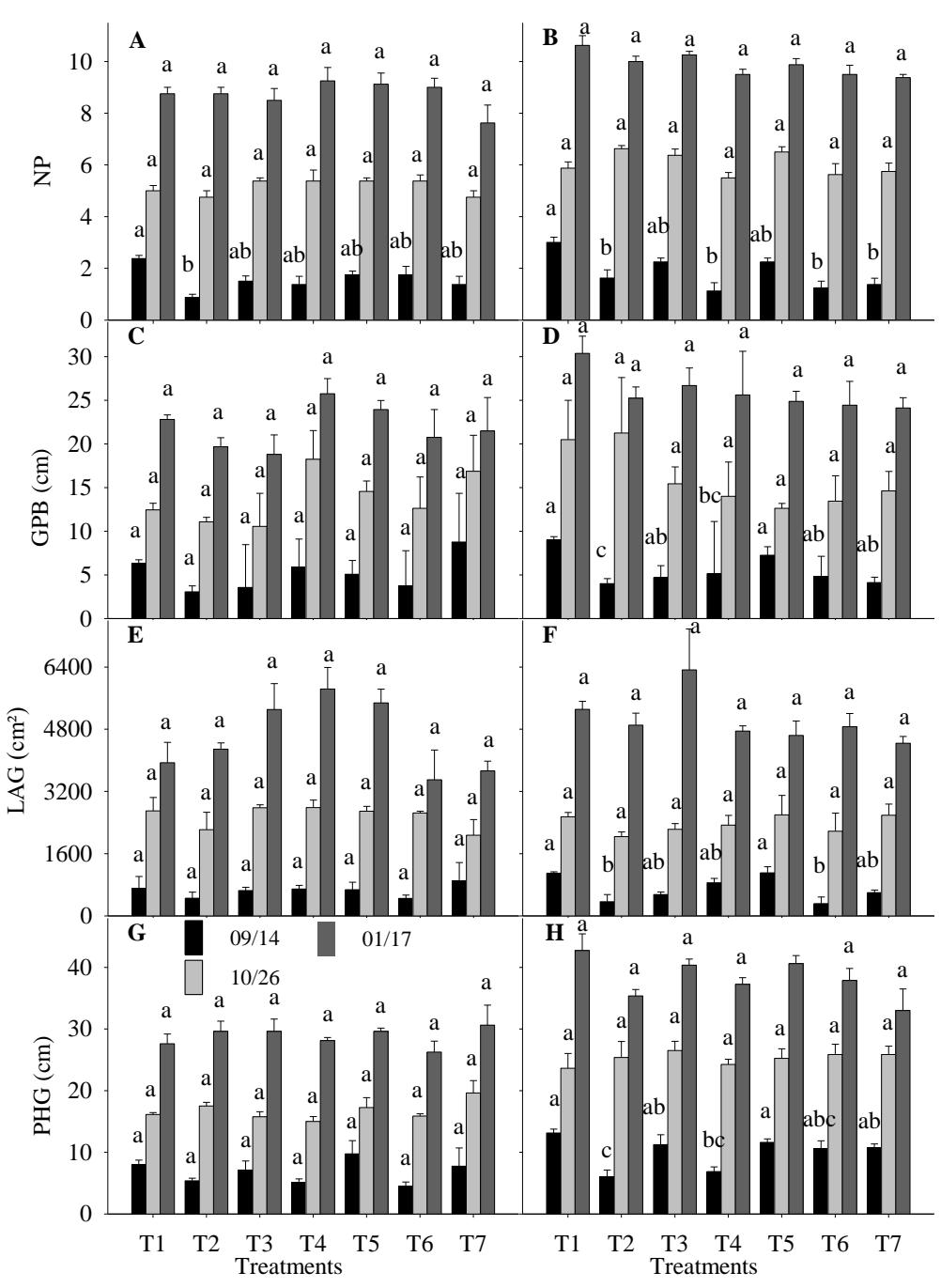

Fig 4. Nodes production (NP- A and B), growth of plagiotropic branches (GPB- C and D), leaf area gains (LAG- E and F) of the plagiotropic branch and plant height gains (PHG - G and H) measured on three dates (09/14, 10/26, and 01/17), in the cultivars 'Catuaí Vermelho IAC 144' (left) and 'Bourbon Amarelo J9' (right) for the different treatments. For each date, bars associated with the same letter indicate no significant differences between treatments (Tukey's test; $p>0.05$ ). See Figure 1 for a description of the treatments.

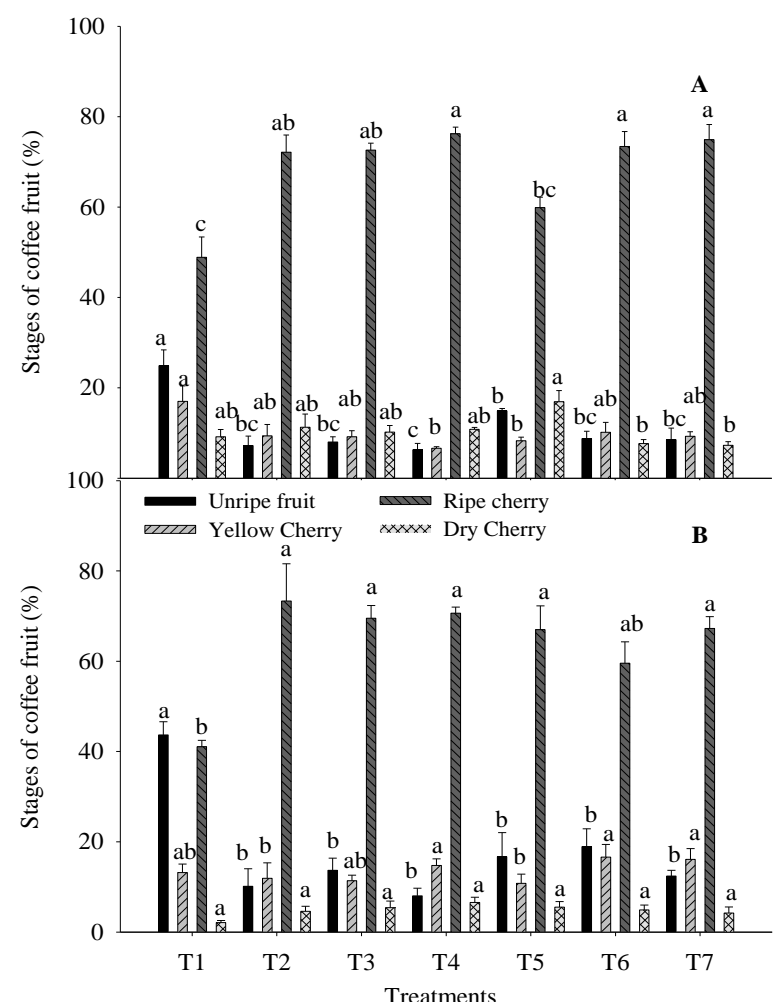

Fig 5. Percentage of each development stage (unripe fruit, yellow cherry, ripe cherry, and dry cherry) of coffee fruits from crops submitted to treatments with different water deficits (T1 to T7) in the cultivars 'Catuaí Vermelho' (A) and 'Bourbon Amarelo' (B). For each fruit stage, bars associated with the same letter indicate no significant differences between treatments, as indicated by the Tukey's test set at $5 \%$ probability. See Figure 1 for a description of the treatments. 


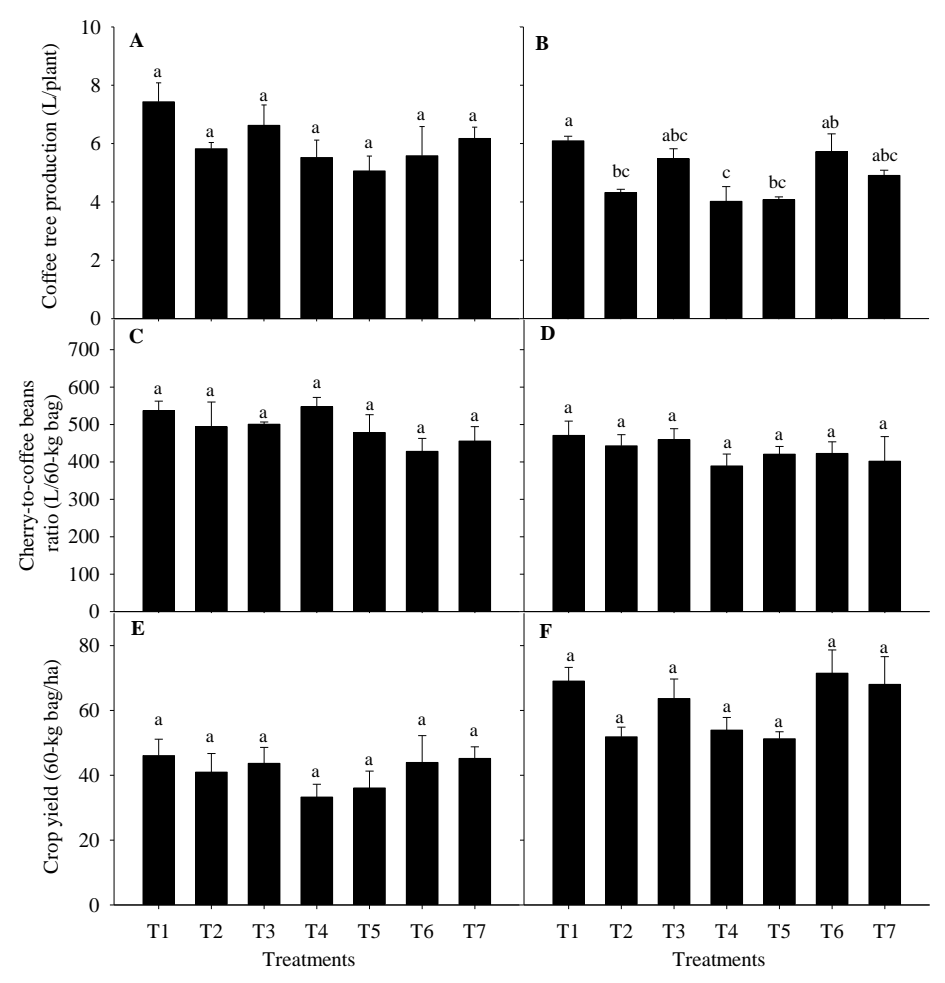

Fig 6. Coffee tree production ( $A$ and $B$ ), cherry-to-coffee beans ratio ( $C$ and $D)$ and crop yield $(E$ and $F$ ) in coffee samples obtained from crops submitted to treatments with different water deficits (T1 to T7) in the cultivars 'Catuaí Vermelho' (on the left) and 'Bourbon Amarelo' (on the right). Bars associated with the same letter indicate no significant differences between treatments (Tukey's test; $p>0.05$ ). Crop yield is expressed as $60-\mathrm{kg}$ bag of fresh green coffee bean per ha. See Figure 1 for a description of the treatments.

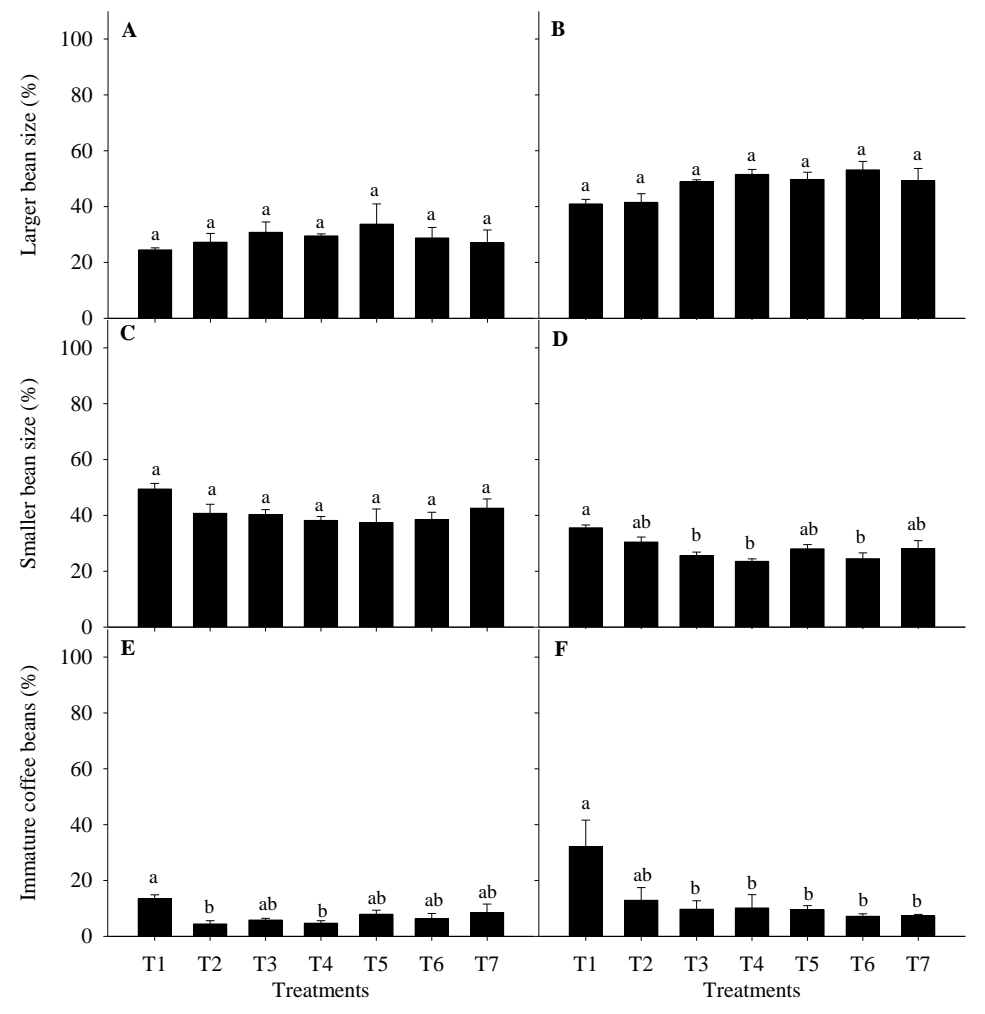

Fig 7. Percentage of coffee beans of larger (from 7.14 to $6.74 \mathrm{~mm}$ ) (A and B) and smaller (from 6.35 to $5.56 \mathrm{~mm}$ ) (C and D) size and immature coffee beans ( $E$ and $F$ ) for the different water deficit treatments in cultivars 'Catuaí Vermelho' (left) and 'Bourbon Amarelo' (right). Bars associated with the same letter indicate no significant differences between treatments (Tukey's test; $p>$ 0.05). See Fig 1 for a description of the treatments. 
Together, these results suggest that regardless of the cultivar and failure to obtain the concentration of flowering in a single event, the application of the water deficit in the pre-flowering period contributed to uniform maturation of arabica coffee fruit. The high percentage of cherry beans is extremely desirable, since this is the most adequate stage (Mesquita et al., 2016) to obtain high quality beverages, as the fruit has a suitable chemical composition (Pimenta et al., 2018). Another problem related to the lack of uniformity in fruit maturation is the impaired operational performance of the mechanized harvesting process (DaMatta et al., 2007), a common practice in the Brazilian Cerrado region (Fernandes et al., 2012), which facilitates higher yields and lower costs under favorable fruit maturation conditions (Mesquita et al., 2016).

\section{Coffee yield and bean quality}

Significant variation among treatments in the coffee production per plant occurred only in 'Bourbon' but not in 'Catuaí' (Figs. 6A and B) (Fig. 6B), the treatments did neither affect the cherry-to-beans ratio (Figs. $6 C$ and $D$ ) nor the crop yield (Figs. $6 \mathrm{E}$ and $\mathrm{F}$ ). This differs from the results reported by Bomfim Neto (2007) and Silva et al. (2009), who obtained higher yields as the severity of the deficit was reduced. Our results are consistent with observations by Soares et al. (2005) and Ronchi et al. (2015) that a controlled water deficit does not affect coffee productivity. However, it should be noted that an excessive water deficit impairs the physiological functions of the coffee tree (Ronchi and Miranda, 2020), leading to photosynthetic limitations due to reduced stomatal conductance and biochemical limitations related to $\mathrm{CO}_{2}$ fixation (Peloso et al., 2017). It can also lead to reductions in leaf area, plant height, root diameter, and coffee tree dry matter (Peloso et al., 2017), and consequently undesirable future losses as reported by Guerra et al. (2005).

In 'Catuai', there were no differences between treatments for the coffee bean size classified (see material and methods) as larger or smaller sizes (Figs. 7A and C), consistent with the results reported by Ronchi et al. (2015) and Silva et al. (2009). In 'Bourbon', despite the statistical differences between the treatments for the smaller sized coffee beans (Fig. 7D), there was no pattern that clearly indicated any effect of the water deficit. Moreover, there were no differences between treatments for the larger sized coffee beans (Fig. 7B). This was probably because the water restriction was applied long before the rapid swelling, expansion, and endosperm filling stages, when the maximum seed size and its content are defined (DaMatta et al., 2007). While larger coffee beans tend to be valued more than the smaller ones in the coffee market, the presence of immature (or green) beans, which contribute to beverage astringency, can negatively influence the coffee price (Franca and Oliveira, 2008). In the present study, a lower percentage of immature beans was detected in almost all deficit treatments, regardless of the cultivar (Figs. 7E and F), reinforcing the validity of the controlled water deficit applied in the pre-flowering stage as a method to standardize the coffee fruit ripening.
Materials and Methods

\section{Plant materials}

A field-experiment was conducted from June 2008 to July 2009 , in a commercial coffee crop (latitude: $19^{\circ} 14^{\prime} \mathrm{S}$; longitude: $46^{\circ} 21^{\prime} \mathrm{W}$; elevation: $900 \mathrm{~m}$ ) located in the city of Rio Paranaíba, Minas Gerais state, Brazil. Two Coffea arabica fields were used, one with the cultivar 'Catuai Vermelho IAC 144 ' and the other with the cultivar 'Bourbon Amarelo J9'. Both cultivars were transplanted to the field in December 2006 , with a spacing of $3.80 \times 0.50 \mathrm{~m}$ ('Catuai') and $3.80 \times$ $0.80 \mathrm{~m}$ ('Bourbon'). Thus, the coffee plants were 19-year old when the treatments were applied. These cultivars were selected as the 'Catuai'-type is extensively cultivated in the Cerrado of Minas Gerais (Fernandes et al., 2012), and the 'Bourbon'-type has a high productivity potential (Ferreira et al., 2013) and can produce special coffees (Figueiredo et al., 2018). The general cultivation practices (weed management, fertilization, phytosanitary control, etc.) were performed according to the agronomic recommendations adopted in the Cerrado (Matiello et al., 2016). The crops were fertigated and the experimental areas were located in adjacent plots, separated only by a trodden path.

\section{Experimental design and treatments}

Each cultivar ('Catuaí Vermelho' or 'Bourbon Amarelo') constituted a separate experiment. A randomized block design was followed, and blocks were arranged perpendicular to the slope of the area, with seven treatments and four replicates. Each experimental unit comprised a cultivation line with eight plants, and the four central plants were used for measurements. Irrigation was suspended and resumed at different times, providing the following treatments: T1: irrigated continuously; T2: 06/09 to $09 / 07$ - 90 days of deficit; T3: $06 / 23$ to $08 / 25$ - 63 days of deficit; T4: 06/23 to 09/07 - 76 days of deficit; T5: 07/07 to 08/25 - 49 days of deficit; T6: 07/07 to 09/07 - 62 days of deficit; T7: 07/21 to 09/07 - 48 days of deficit.

The induced water deficit periods were chosen based on the studies of Guerra et al. (2005) and Soares et al. (2005), and on the meteorological conditions of that crop year (2008, Fig 2). Moreover, the water deficit period (by withholding irrigation) usually applied in this coffee farm over the past years was also used as a reference. In this coffee farm, irrigation was usually withdrawn in early July and resumed in late August, which corresponded exactly to T5. Based on this, in some treatments the irrigation suspension began sooner as in early June or later as by the end of July. Similarly, its resumption was postponed until September (or as much as possible), close to the first expected rains of the season.

\section{Traits measured}

\section{Pre-dawn leaf water potential}

The $\Psi_{\mathrm{w}_{\mathrm{pd}}}$ was measured biweekly from $06 / 30$, between 4 and $6 \mathrm{AM}$, using a pressure pump (Scholander pressure chamber, Soilmoisture - Santa Barbara, USA). It was evaluated in one leaf per plot, collected in the third or fourth branch node from the apex of the plagiotropic branches 
located in the upper third of the plant.

\section{Flower bud stages}

The developmental stages of the flower buds were recorded from August to mid-October, in four flowering events (the final flowerings were not evaluated): first, on $08 / 17$ (because of the $8 \mathrm{~mm}$ rain on 08/05); second, on 09/14 (because of the resumption of irrigation in the treatments); third, on 09/28 (because of the $39 \mathrm{~mm}$ rain from 09/15-21); and fourth, on 10/09 (because of the $30 \mathrm{~mm}$ rain on 10/02). All reproductive structures were collected from four branch nodes per plot, which were randomly selected from two previously identified branches in the medial portion of the plagiotropic branch. In the laboratory, the flower bud development stages were classified according to CamayoVélez and Arcila-Pulgarín (1996) as: E3-physiologically immature flower bud. In this stage, flower buds are already greater than node stipules; even though they can be easily counted they are not yet completely individualized at theglomerule inflorescence. E4 - physiologically mature flower bud (ripe-to-flower stage), the individual flower bud is green and completely discernible at each glomerule. They remain in this state until an external stimulus brings about a renewal of growth. E5 - is after the break in dormancy, just before anthesis, when the buds appear completely white; and E6 - anthesis (opened flowers). Flower buds at stages less than E3 were not counted. For discussion E3+E4 were combined just as "flower buds" and E5+E6 as "opened flowers". The number of pinheads (representing early fruit stage) was also counted.

\section{Plant growth increment}

Coffee plant growth was measured during and after the deficit period, on 06/22 (close to the start of the treatments), 09/14 (after irrigation resumption but before the expected first rains of the season), 10/26 (transition from the pinhead stage to rapid swelling expansion), and finally in the following year, on 01/17 (start of the endosperm filling stage). As a measure of plant height, the distance from the hypocotyl to the apex of the plant was recorded. The number of nodes was counted in randomly selected plagiotropic branches (one bearing branch per plant) in the middle third of the coffee tree. The length of these branches was also measured, and the total leaf area was estimated non-destructively based on the length and width of the leaf blade (Antunes et al., 2008). For each growth variable and evaluation time, the growth increment was calculated using the value of the first measurement (on $06 / 22$ ) as a reference.

\section{Post-harvesting fruit evaluations}

The four central plants of each plot were harvested in June 2009 by manual stripping on canvas (full harvest), followed by measuring production of coffee fruits per plant (L/plant). Then, the percentage of each ripening stage of coffee fruits (unripe, yellow cherry, ripe cherry, and dried cherry) was measured in $0.5 \mathrm{~L}$ samples, following the method described by Ronchi et al. (2015). The coffee was taken to a yard, spread out, rotated daily until it was dried, and husked to obtain bean coffee at a moisture content of $11.5 \%$. Then, the crop yield expressed as 60-kg bag of green coffee per ha was estimated for each cultivar. The ratio of harvested fruit volume to $60-\mathrm{kg}$ bag of bean coffee, here described as cherry-to-coffee bean ratio was estimated (as L/60-kg bag). The physical analysis of the beans was performed using the standard procedure for coffee bean classification. A sample of $100 \mathrm{~g}$ of coffee beans was passed through a series of sieves with holes of different diameter, after which weight fractions retained on each sieve were converted to weight percentages of the total sample (Imru et al., 2015). Fractions were combined forming two classes of coffee bean diameter: larger sizes (from 7.14 to $6.74 \mathrm{~mm}$ ) and smaller sizes (from 6.35 to $5.56 \mathrm{~mm}$ ). Coffee beans smaller than $0.556 \mathrm{~cm}$-diameter were not considered in this study. The percentage of immature coffee beans (green or light grey beans), representing, green coffee defect, was also evaluated.

\section{Statistical analysis}

Descriptive analyses of the meteorological data and leaf water potential were performed. For the other variables (flower buds, plant growth, and coffee yield and quality), the normality and homoscedasticity of the errors were analyzed using the Lilliefors and Cochran's tests, respectively, together with a graphical residue analysis (Neter et al., 1990). When required, the data were square-root transformed. The data were then subjected to analysis of variance (ANOVA) and to multiple comparisons of means, using the Tukey's test set at 5\% probability.

\section{Conclusion}

Although the cultivation conditions were the same, 'Catuai' showed more negative water potential in comparison to 'Bourbon', for the same deficit period. Thus, the irrigation resumption induced a more intense flowering in that cultivar. The developmental stage of the floral bud must be considered for the application of the water deficit along with the cultivar and water deficit level and not the dates when the irrigation is suspended or resumed. The water deficit contributed to the concentration of flowering and not only to a single intense blossoming event. Irrigation suspension, regardless of treatment, promoted a satisfactory synchronization of the fruit maturation (more cherries and less green beans) without compromising plant growth and the physical quality of the beans.

\section{Acknowledgments}

This work was supported by 'Fundação de Amparo à Pesquisa do Estado de Minas Gerais' - FAPEMIG (grant FORTIS-TCT-10254/2014). We also thank the Fazenda Transagro S.A., for extending the use of the experimental area.

\section{References}

Alvim PT (1960) Moisture stress as a requirement for flowering of coffee. Science. 132:354.

Amaral JAT, Rena AB, Amaral JFT (2006) Crescimento vegetativo sazonal do cafeeiro e sua relação com fotoperíodo, frutificação, resistência estomática e 
fotossíntese. Pesq Agropec Bras. 41:377-384.

Antunes WC, Pompelli MF, Carretero DM, DaMatta FM (2008) Allometric models for non-destructive leaf area estimation in coffee (Coffea arabica and Coffea canephora). Ann Appl Biol. 153:33-44.

Batista LA, Guimarães RJ, Pereira FJ, Carvalho GR, Castro EM (2010) Anatomia foliar e potencial hídrico na tolerância de cultivares de café ao estresse hídrico. Ver Cienc Agron. 41:475-481.

Bomfim Neto H (2007) Influência do deficit hídrico na floração do cafeeiro arábico, monitorado pelo desenvolvimento do botão floral e potencial hídrico da planta. Dissertação (Mestrado) - Universidade Federal de Viçosa. Viçosa, Brazil. 36p.

Camayo-Vélez GC, Arcila-Pulgarín J (1996) Estudio anatómico y morfológico de La diferenciación y desarrollo de las flores Del café to Coffea arabica I variedad Colombia. Cenicafé. 47:121-139.

Conab (2018) Acompanhamento da safra brasileira: café: safra 2018 - terceiro levantamento - setembro/2018. Brasília: Conab, v.5, n.3, September 2018. Available at: $<$ https://www.conab.gov.br/info-

agro/safras/cafe/boletim-da-safra-de-cafe/item/10014-3levantamento-cafe-safra-2018.> Accessed on October 13, 2018.

Crisosto CH, Grantz DA, Meinzer FC (1992) Effect of water deficit on flower opening in coffee (Coffea arabica L.). Tree Physiol. 10:127-139.

DaMatta FM, Ronchi CP, Maestri M, Barros RS (2007) Ecophysiology of coffee growth and production. Braz J Plant Physiol. 19:485-510.

Fernandes ALT, Partelli FL, Bonomo R, Golynski A (2012) A moderna cafeicultura dos Cerrados brasileiros. Pesq Agropec Trop. 42:231-240.

Fernandes ALT, Tavares TO, Santinato F, Ferreira RT, Santinato R (2016) Viabilidade técnica e econômica da irrigação localizada do cafeeiro, nas condições climáticas do planalto de Araxá, MG. Coffee Sci. 11:346-357.

Ferreira AD, Carvalho GR, Rezende JC, Botelho CE, Rezende RM, Carvalho AM (2013) Desempenho agronômico de seleções de café Bourbon vermelho e Bourbon Amarelo de diferentes origens. Pesq Agropec Bras. 48:388-394.

Figueiredo LP, Borém FM, Ribeiro FC, Giomo GS, Malta MR, Taveira JHS (2018) Sensory analysis and chemical composition of 'bourbon' coffees cultivated in different environments. Coffee Sci. 13:122-131.

Franca AS, Oliveira LS (2008) Chemistry of defective coffee beans. In: Koeffer EN (ed) Progress in Food Chemistry, 1st edn. Nova Science Publishers, New York.

Guerra AF, Rocha OC, Rodrigues GC (2005) Manejo do cafeeiro irrigado no Cerrado com estresse hídrico controlado. Irrig Tecnol Mod. 65/66:42-45.

Imru NO, Wogderess MD, Gidada TV (2015) A study of the effects of shade on growth, production and quality of coffee (Coffea arabica) in Ethiopia. Int JAgr Sci. 5:748-752.

Matiello JB, Santinato R, Almeida SR, Garcia AWR (2016) Cultura de café no Brasil: manual de recomendações: ed. 2015. MAPA/PROCAFE, Rio de Janeiro, Brazil. 585 p.

Mesquita CM, Rezende JE, Carvalho JS, Fabri Júnior MA, Moraes NC, Dias PT, Carvalho RM, Araújo WG (2016) Manual do café: colheita e preparo (Coffea arabica L.). EMATER-MG, Belo Horizonte, Brazil. $50 \mathrm{p}$.

Neter J, Wasserman W, Kutner MH (1990) Applied linear statistical models: regression, analysis of variance and experimental designs. Irwin, Burr Ridge, United States of America. 1181p.

Peloso AF, Tatagiba SD, Amaral JFT (2017) Limitações do crescimento vegetativo em cafeeiro arábica promovido pelo deficit hídrico. Eng Agr. 25:139-147.

Pimenta CJ, Angélico CL, Chalfoun SM (2018) Challenges in coffee quality: cultural, chemical and microbiological aspects. Ciênc Agrotec. 42:337-349.

Rees AR (1964) Some observations on the flowering behaviour of Coffea rupestris in southern Nigeria. J Ecol. 52:1-7.

Ronchi $\mathrm{CP}$, Araújo $\mathrm{FC}$, Almeida WL, Silva MAA, Magalhães CEO, Oliveira LB, Drumond LCD (2015) Respostas ecofisiológicas de cafeeiros submetidos ao deficit hídrico para concentração da florada no Cerrado mineiro. Pesq Agropec Bras. 50:24-32.

Ronchi CP, Miranda FR (2020). Flowering percentage in arabica coffee crops depends on the water deficit level applied during the pre-flowering stage. Rev. Caatinga. 33:195-204.

Schuch UK, Fuchigami LH, Nagao MA (1992) Flowering, ethylene production, and ion leakage of coffee in response to water stress and gibberellic acid. J Am Soc Hortic Sci. 117:158-163.

Silva EA, Brunini O, Sakai E, Arruda FB, Pires RC (2009) Influência de deficits hídricos controlados na uniformização do florescimento e produção do cafeeiro em três diferentes condições edafoclimáticas do estado de São Paulo. Bragantia. 68:493-501.

Soares AR, Mantovani EC, Rena AB, Soares AA (2005) Irrigação e fisiologia da floração em cafeeiros adultos na região da zona da mata de Minas Gerais. Acta Sci Ag. 27:117-125.

Taiz L, Zeiger E, Moller IM, Murphy A (2017) Plant physiology \& development, 6th edn. Sinauer Associates, Oxford. $761 p$. 